\title{
Amazon rainforests green-up with sunlight in dry season
}

\author{
Alfredo R. Huete, ${ }^{1,2}$ Kamel Didan, ${ }^{1}$ Yosio E. Shimabukuro, ${ }^{3}$ Piyachat Ratana, ${ }^{1}$ \\ Scott R. Saleska, ${ }^{2,4}$ Lucy R. Hutyra, ${ }^{5}$ Wenze Yang, ${ }^{6}$ Ramakrishna R. Nemani, \\ and Ranga Myneni ${ }^{6}$
}

Received 23 December 2005; revised 6 February 2006; accepted 8 February 2006; published 22 March 2006.

[1] Metabolism and phenology of Amazon rainforests significantly influence global dynamics of climate, carbon and water, but remain poorly understood. We analyzed Amazon vegetation phenology at multiple scales with Moderate Resolution Imaging Spectroradiometer (MODIS) satellite measurements from 2000 to 2005. MODIS Enhanced Vegetation Index (EVI, an index of canopy photosynthetic capacity) increased by $25 \%$ with sunlight during the dry season across Amazon forests, opposite to ecosystem model predictions that water limitation should cause dry season declines in forest canopy photosynthesis. In contrast to intact forests, areas converted to pasture showed dry-season declines in EVI-derived photosynthetic capacity, presumably because removal of deep-rooted forest trees reduced access to deep soil water. Local canopy photosynthesis measured from eddy flux towers in both a rainforest and forest conversion site confirm our interpretation of satellite data, and suggest that basin-wide carbon fluxes can be constrained by integrating remote sensing and local flux measurements. Citation: Huete, A. R., K. Didan, Y. E. Shimabukuro, P. Ratana, S. R. Saleska, L. R. Hutyra, W. Yang, R. R. Nemani, and R. Myneni (2006), Amazon rainforests green-up with sunlight in dry season, Geophys. Res. Lett., 33, L06405, doi:10.1029/2005GL025583.

\section{Introduction}

[2] The mechanisms controlling tropical rainforest phenology and productivity are not well understood. Site-based plot and flux tower results in old-growth Amazon rainforests are ambiguous with some studies showing depressed photosynthetic activity in the dry season due to moisture stress [Malhi et al., 1998] while other studies show dry season increases in total canopy photosynthesis [Saleska et $a l ., 2003]$ and species-specific shoot and leaf growth [Borchert, 1994] with little evidence of stress possibly because deep tree roots allow continuous access to deep

\footnotetext{
${ }^{1}$ Department of Soil, Water and Environmental Science, University of Arizona, Tucson, Arizona, USA.

${ }^{2}$ Institute for the Study of Planet Earth, University of Arizona, Tucson, Arizona, USA.

${ }^{3}$ Instituto Nacional de Pesquisas Espaciais, São José dos Campos, Brazil.

${ }^{4}$ Department of Ecology and Evolutionary Biology, University of Arizona, Tucson, Arizona, USA.

${ }^{5}$ Department of Earth and Planetary Sciences, Harvard University, Cambridge, Massachusetts, USA.

${ }^{6}$ Department of Geography, Boston University, Boston, Massachusetts, USA.

${ }^{7}$ NASA Ames Research Center, Moffett Field, California, USA.
}

Copyright 2006 by the American Geophysical Union. 0094-8276/06/2005GL025583\$05.00 soil moisture layers, even during the dry season [Nepstad et al., 1994; da Rocha et al., 2004; Oliveira et al., 2005]. Several prominent ecosystem models, by contrast, show significant 'brown-down' in the dry season as a consequence of increasing dry-season water stress [Botta et al., 2002; Tian et al., 1998] with other model studies suggesting Amazon tropical rainforests are light-limited [Nemani et al., 2003].

[3] In the seasonally dry, central and eastern Amazon rainforests, photosynthesis begins to decline in the late wet season, most likely a result of onset of senescence and litterfall and envelopment of mature leaves by epiphylls (moss, algae) that inhibit photosynthesis [Goulden et al., 2004; Roberts et al., 1998]. Litterfall peaks in the early dry season followed by a period of rapid leaf turnover with significant increases in leaf area and photosynthesis [Asner et al., 2004; Carswell et al., 2002; Saleska et al., 2003; Rice et al., 2004]. Leaf flushing in several rainforests, including central Amazônia, has been found to closely coincide with dry season peaks in photosynthetic active radiation (PAR) [Wright and van Schaik, 1994] which is mostly controlled by seasonal cloud cover variations [da Rocha et al., 2004].

[4] At the basin scale, a more complex regional mosaic of vegetation phenology can be expected as a result of forest structural variations, land use activities, and associated ecological conditions [Asner et al., 2004; Keller et al., 2004]. Photosynthesis has been found more tightly coupled with water availability in the drier and transitional, southern Amazon rainforests that have lower biomass and leaf area index (LAI) [von Randow et al., 2004; Vourlitis et al., 2001]. In this study, we analyzed vegetation phenology and seasonal patterns in rainforest greening over the entire Amazon basin $\left(7.5 \times 10^{6} \mathrm{~km}^{2}\right)$ using satellite observations.

\section{Methods}

[5] Rainforest seasonality was analyzed at multiple scales, including (1) an extensive $2,000 \mathrm{~km}$ climate transect through eastern and central Amazônia, (2) basin-wide, and (3) local forest and conversion (pasture or agricultural) sites in eastern Amazônia. We used Enhanced Vegetation Index (EVI) satellite data from the recently launched Terra Moderate Resolution Imaging Spectroradiometer (MODIS) sensor [Justice et al., 1998]. Previous satellite observations with NOAA Advanced Very High Resolution Radiometer (AVHRR) measurements were constrained by cloud contamination and sensitivity to seasonally variable atmosphere water vapor and aerosol conditions, as well as poor spatial resolution ( $>4 \mathrm{~km})$ [Kobayashi and Dye, 2005]. In contrast, the MODIS sensor offers new opportunities for basin-wide Amazon studies with state of the art calibration, atmosphere correction, narrower spectral bands without water vapor 

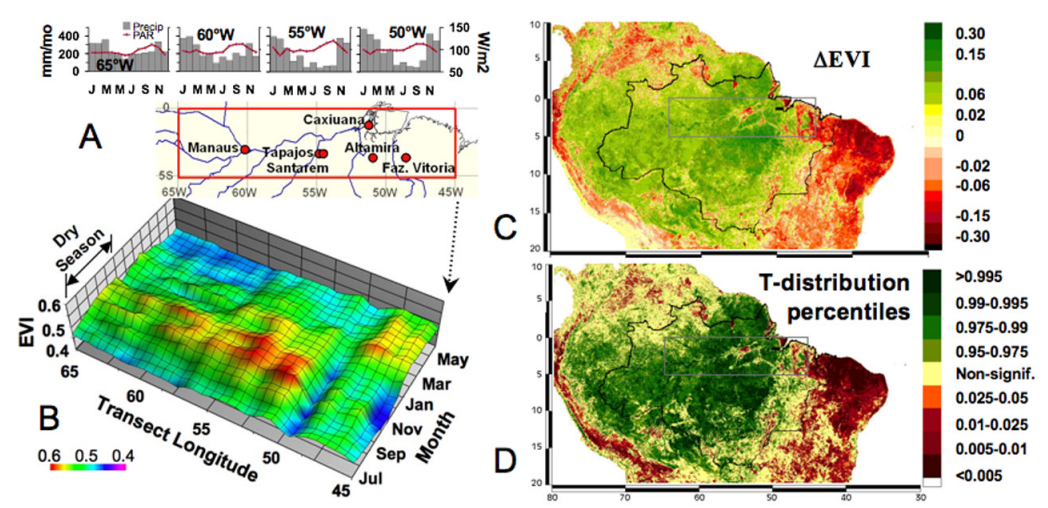

Figure 1. Climate transect and basin analysis. (a) Map of transect area and mean climate data, $0.5^{\circ}$ PAR [Pinker, 2002] and $0.25^{\circ}$ Tropical Rainfall Measuring Mission (TRMM) precipitation data [http://disc.gsfc.nasa.gov/precipitation/]. (b) 5-year mean seasonal EVI along climate-transect. (c) Basin-wide image of average EVI change ( $\Delta \mathrm{EVI})$ between June and October with green colors depicting 'greening' and red colors depicting 'browning' in the dry season. (d) Statistical significance of $\Delta E V I$ patterns, quantified as percentiles of T-distribution under null hypothesis that $\Delta E V I$ is equal to zero (paired T-test, $\mathrm{n}=6$ years per pixel). High percentiles indicate statistically significant green-up, and low percentiles indicate statistically significant brown-down.

influences, finer resolution $(250 \mathrm{~m})$ observations that facilitate cloud-filtering, and newly developed terrestrial products [Justice et al., 1998].

[6] Vegetation indices measure canopy greenness, a composite property of canopy structure, leaf area, and canopy chlorophyll content [Myneni et al., 1995]. The EVI maintains sensitivity even in high LAI canopies, such as found throughout the Amazon (LAI > 4), by relying on nearinfrared canopy reflectance which is less prone to saturate, particularly with moderate resolution pixels [Gao et al., 2000; Huete et al., 2002]. As has been noted through theoretical analyses, spectral indices more functional on the near-infrared best describe area-averaged canopy photosynthetic capacities and gross primary production (GPP) [Sellers et al., 1992]. EVI has been shown to correlate well with GPP over a range of temperate North American biome types [Rahman et al., 2005].

\subsection{Climate Transect and Basin Analysis}

[7] A climate transect of variable rainfall and PAR seasonality across eastern and central Amazon rainforests $\left(47^{\circ}\right.$ to $64^{\circ} \mathrm{W}$ and $0^{\circ}$ to $\left.5^{\circ} \mathrm{S}\right)$ was divided into 34 strips (70 km wide by $500 \mathrm{~km}$ long) and 16-day composited EVI at $250 \mathrm{~m}$ resolution were averaged from 2000 to 2005 into a single year using quality assurance (QA) metrics to filter out poor data (Figure 1a). Dry season lengths (defined as consecutive monthly rainfall less than $100 \mathrm{~mm}$ ) varied from 4 to 5 months in eastern Amazon forests (Tapajós and Caxiuanã) to 2 to 3 months near Manaus in central Amazon and 1-2 months west of Manaus [Sombroek, 2001]. Seasonal and spatial variations in PAR were closely associated with dry season periods (Figure 1a). The easternmost portion of the transect was in the 'arc of deforestation' with mixed pastures, agriculture, and secondary forests. A basin-wide depiction of observed phenology patterns was created by subtracting dry and wet season EVI values (October - June) using monthly climate modeling grid (CMG) data consisting of
QA-filtered, good quality $1 \mathrm{~km}$ pixels aggregated to $0.05^{\circ}$ and averaged from 2000 to 2005 .

\subsection{Site Extracts}

[8] Small subsets of $250 \mathrm{~m}$ EVI $(7 \times 7$ pixels $)$ were averaged over 5 years for a series of Large-scale Biosphere-Atmosphere Experiment in Amazônia (LBA) core research sites with known site conditions [Keller et al., 2004]. Two Santarém forest sites, km 83 (3.03 S, 54.97 W) and $\mathrm{km} 67(2.86 \mathrm{~S}, 54.96 \mathrm{~W})$ are in the Floresta Nacional do Tapajós in the state of Pará and have canopy heights of $\sim 40 \mathrm{~m}$ with LAI of 5-7 [Rice et al., 2004; Goulden et al., 2004]. Another forest site is in the Floresta Nacional do Caxiuanã $(1.75 \mathrm{~S}, 51.45 \mathrm{~W})$ near the mouth of the Amazon River with canopy heights of $\sim 35 \mathrm{~m}$, LAI 5 -7 [Carswell et al., 2002]. The forest conversion sites near Santarém (km 77, 3.02 S, 54.89 W), Altamira (3.24 S, $52.3 \mathrm{~W})$, and Fazenda Vitoria $(2.96 \mathrm{~S}, 47.41 \mathrm{~W})$ have similar rainfall (2000-2200 mm) and dry season periods (4-5 months) as the forest sites [Sombroek, 2001]. A smaller subset of EVI $(3 \times 3)$ was also compared with local canopy photosynthesis measured from eddy flux towers at the Tapajós forest site ( $\mathrm{km} \mathrm{67)} \mathrm{[Saleska} \mathrm{et} \mathrm{al.,}$ 2003] and Santarém pasture site ( $\mathrm{km} \mathrm{77)} \mathrm{[Sakai} \mathrm{et} \mathrm{al.,}$ 2004]. Average canopy photosynthesis (measured in terms of GPP in $\mathrm{kgC} / \mathrm{m}^{2} /$ month) was estimated as the difference between average nighttime and average daytime Net Ecosystem Exchange [Saleska et al., 2003].

\section{Results}

[9] We found widespread greening in the dry season along the climate transect spanning central and eastern Amazon rainforests (Figure 1b). A broad green-up region of varying intensities was observed from $65^{\circ} \mathrm{W}$ to $50^{\circ} \mathrm{W}$ with the most pronounced green-up (EVI increases of 25\%) in the more seasonally-dry (4-5 month) eastern Amazon with greening becoming weaker in central Amazon with 


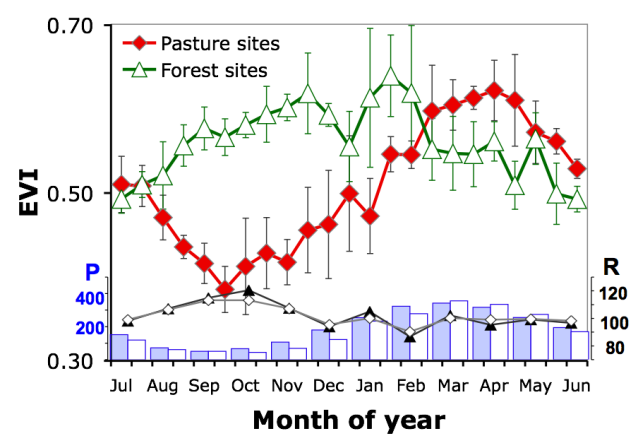

Figure 2. 5-year mean seasonal EVI at local forest and conversion sites with PAR (lines) and long-term station rainfall [http://www.ncdc.noaa.gov/oa/climate/research/ ghcn/ghcn.html] in the Tapajós (shaded) and Caxiuanã regions.

shorter dry season periods (1-3 month). A complete reversal in phenology ('brown-down') can be seen in the easternmost portion of the transect where extensive forest conversion has resulted in more shallow-rooted vegetation with reduced access to deep soil waters that persist through the dry season. Our basin-wide analysis showed dry season greening prevalent throughout the basin, particularly in the seasonally-dry eastern Amazon rainforests (Figure 1c). $48.3 \%$ of the basin exhibited significant greening in dry season (>.975 percentile) and $29.4 \%$ of Amazon forests were strongly significant in greening (>.995) (Figure 1d).

[10] We observed patterns of green-up in primary forests and brown-down in pastures across the local study sites (Figure 2). Greenness values at rainforest sites followed PAR and increased by $25 \%$ from beginning to the end of the dry season (July-November), which was opposite that found in the pasture sites where greenness values were closely coupled to rainfall and decreased by as much as $25 \%$ in the dry season in response to soil moisture stress. The observed seasonality in EVI was consistent with flux tower measurements of GPP from the Tapajós forest and Santarém converted sites: both MODIS EVI and towerbased GPP show dry season increases and late wet season declines in forest photosynthesis (Figure 3a), and both reproduce the inverse seasonal pattern in the pasture/ cropland site (Figure 3b). The proximity of the Tapajós forest and Santarém pasture sites ( $\sim 15 \mathrm{~km}$ apart), along with close agreement between satellite-EVI and tower-GPP results, are strong evidence against artifacts (residual clouds, sensor geometry) in the satellite-observed phenology. The consistent correlation between tower GPP and EVI in both forest and converted land $\left(\mathrm{r}^{2}=0.5\right.$, Figure $\left.3 \mathrm{c}\right)$ suggests that basin-wide carbon fluxes could be constrained by integrating remote sensing and local flux measurements. Also accounting for environmental variations (e.g. in sunlight) should improve remote sensing estimates of GPP. Xiao et al. [2005] attempted this at one forest site, but achieved no better estimates of tower GPP than shown here using EVI alone.

\section{Conclusions}

[11] This study confirms plot-based studies in the Amazon and other rainforests documenting flushes of new leaf growth with increased photosynthesis in the dry season that closely coincide with seasonal peaks in solar irradiance [Saleska et al., 2003; Wright and van Schaik, 1994]. Our results show basin-wide enhanced rainforest activity in the sunnier dry season, suggesting that sunlight may exert more influence than rainfall on rainforest phenology and productivity. This was opposite that encountered over areas of forest conversion that brown-down with moisture stress in the dry season due to their shallower rooting depths.

[12] Both climatic and human drivers, as well as ecological conditions may alter the balance of moisture and sunlight controls on rainforest metabolism with global implications to climate, carbon, and water dynamics. Our observations do not extend through an El Niño cycle and so our conclusions on dry season greening are limited to typical rainfall years. During the stronger drought of an El Niño period, green-up may be prevented if even deep roots are insufficient to overcome dry-season rainfall deficits, a possibility supported by a drought-simulation experiment [Nepstad et al., 2002] and AVHRR observations through previous El Niño years [Asner et al., 2000]. Deforestation and land use pressures may also shift sunlight and moisture controls on Amazon phenology with important consequences to sustainable land use in Amazônia.

[13] MODIS EVI data depicted seasonal patterns in greenness with high fidelity. This was supported with local canopy photosynthesis measured from eddy flux towers in both a primary forest and a converted pasture/cropland. The consistent relationship between tower GPP and EVI, found in this study, suggests that basin-wide carbon fluxes can be constrained through integration of satellite data and local flux measurements.
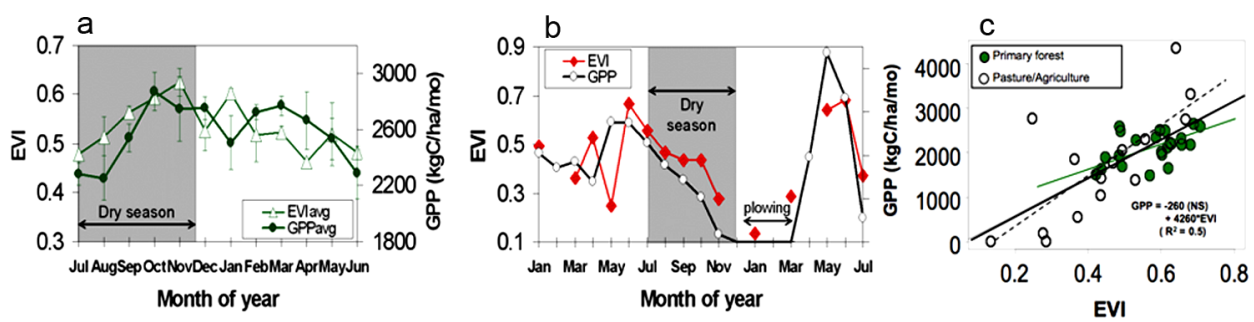

Figure 3. Vegetation seasonal phenology (mean \pm standard error across years). (a) Satellite EVI and local tower GPP at Tapajós primary forest (km 67 site, 2002-2004), and (b) satellite EVI and local tower GPP [Sakai et al., 2004] for January 2001 -June 2002 in Santarém pasture/cropland (km 77 site, converted from pasture to rice cultivation in late 2001, after which the field was bare for several months). (c) Average monthly local tower GPP vs. satellite EVI for the two sites. Neither the primary forest regression (solid green line) nor the pasture/cropland regression (dashed line) are statistically distinguishable from the composite regression line (solid black line, equation shown) through all data. 
[14] Acknowledgments. This work was funded by MODIS NASA contract NNG04HZ20C and NASA LBA grant NCC5603. We thank Andrew Jacobson with help on CMG analysis and David Fitzjarrald and Ricardo Sakai for the pasture/agriculture site flux tower data.

\section{References}

Asner, G. P., A. R. Townsend, and B. H. Braswell (2000), Satellite observation of EI Niño effects on Amazon forest phenology and productivity, Geophys. Res. Lett., 27, 981-984.

Asner, G. P., D. Nepstad, G. Cardinot, and D. Ray (2004), Drought stress and carbon uptake in an Amazon forest measured with spaceborne imaging spectroscopy, Proc. Natl. Acad. Sci. U. S. A., 101, 6039-6044.

Borchert, R. (1994), Soil and stem water storage determine phenology and distribution of tropical dry forest trees, Ecology, 75, 1437-1449.

Botta, A., N. Ramankutty, and J. A. Foley (2002), Long-term variations of climate and carbon fluxes over the Amazon basin, Geophys. Res. Lett., 29(9), 1319, doi:10.1029/2001GL013607.

Carswell, F. E., et al. (2002), Seasonality in $\mathrm{CO}_{2}$ and $\mathrm{H}_{2} \mathrm{O}$ flux at an eastern Amazonian rain forest, J. Geophys. Res., 107(D20), 8076, doi:10.1029/ 2000JD000284.

da Rocha, H. R., M. L. Goulden, S. D. Miller, M. C. Menton, L. D. V. O. Pinto, H. C. de Freitas, and A. M. S. Figueira (2004), Seasonality of water and heat fluxes over a tropical forest in eastern Amazonia, Ecol. Appl., 14, S22-S32.

Gao, X., A. R. Huete, W. Ni, and T. Miura (2000), Optical-biophysical relationships of vegetation spectra without background contamination, Remote Sens. Environ., 74, 609-620.

Goulden, M. L., S. D. Miller, H. R. da Rocha, M. C. Menton, H. C. de Freitas, A. M. S. Figueira, and C. A. D. de Sousa (2004), Diel and seasonal patterns of tropical forest $\mathrm{CO}_{2}$ exchange, Ecol. Appl., 14, S42-S54.

Huete, A., K. Didan, T. Miura, E. P. Rodriguez, X. Gao, and L. G. Ferreira (2002), Overview of the radiometric and biophysical performance of the MODIS vegetation indices, Remote Sens. Environ., 83, 195-213.

Justice, C., et al. (1998), The Moderate Resolution Imaging Spectroradiometer (MODIS): Land remote sensing for global change research, IEEE Trans. Geosci. Remote Sens., 36, 1228-1249.

Keller, M., et al. (2004), Ecological research in the large-scale biosphereatmosphere experiment in Amazonia: Early results, Ecol. Appl., 14, S3S16.

Kobayashi, H., and D. G. Dye (2005), Atmospheric conditions for monitoring the long-term vegetation dynamics in the Amazon using normalized difference vegetation index, Remote Sens. Environ., 97, 519-525.

Malhi, Y., A. D. Nobre, J. Grace, B. Kruijt, M. G. P. Pereira, A. Culf, and S. Scott (1998), Carbon dioxide transfer over a Central Amazonian rain forest, J. Geophys. Res., 103(D24), 31,593-31,612.

Myneni, R. B., F. G. Hall, P. J. Sellers, and A. L. Marshak (1995), The interpretation of spectral vegetation indexes, IEEE Trans. Geosci. Remote Sens., 33, 481-486.

Nemani, R. R., C. D. Keeling, H. Hashimoto, W. M. Jolly, S. C. Piper, C. J. Tucker, R. B. Myneni, and S. W. Running (2003), Climate-driven increases in global terrestrial net primary production from 1982 to 1999 , Science, 300, 1560-1563.

Nepstad, D. C., C. R. de Carvalho, E. A. Davidson, P. H. Jipp, P. A. Lefebvre, G. H. Negreiros, E. D. da Silva, T. A. Stone, S. E. Trumbore, and S. Vieira (1994), The role of deep roots in the hydrological and carbon cycles of Amazonian forests and pastures, Nature, 372, 666669.

Nepstad, D. C., et al. (2002), The effects of partial throughfall exclusion on canopy processes, aboveground production, and biogeochemistry of an Amazon forest, J. Geophys. Res., 107(D20), 8085, doi:10.1029/ 2001JD000360.
Oliveira, R. S., T. E. Dawson, S. S. O. Burgess, and D. C. Nepstad (2005), Hydraulic redistribution in three Amazonian trees, Oecologia, 145, 354363.

Pinker, R. (2002), Satellite estimates of radiative fluxes in the western hemisphere, Global Land Cover Facil., Univ. of Md., College Park.

Rahman, A. F., D. A. Sims, V. D. Cordova, and B. Z. El-Masri (2005), Potential of MODIS EVI and surface temperature for directly estimating per-pixel ecosystem C fluxes, Geophys. Res. Lett., 32, L19404, doi:10.1029/2005GL024127.

Rice, A. H., E. P. Hammond, S. R. Saleska, L. Hutyra, M. Palace, M. Keller, P. B. de Camargo, K. Portilho, D. F. Marques, and S. C. Wofsy (2004), Carbon balance and vegetation dynamics in an old-growth Amazonian forest, Ecol. Appl., 14, S55-S71.

Roberts, D. A., B. W. Nelson, J. B. Adams, and F. Palmer (1998), Spectral changes with leaf aging in Amazon caatinga, Trees Struct. Funct., 12, $315-325$.

Sakai, R. K., D. R. Fitzjarrald, O. L. L. Moraes, R. M. Staebler, O. C. Acevedo, M. J. Czikowsky, R. da Silva, E. Brait, and V. Miranda (2004), Land-use change effects on local energy, water, and carbon balances in an Amazonian agricultural field, Global Change Biol., 10, 895-907.

Saleska, S. R., et al. (2003), Carbon in Amazon forests: Unexpected seasonal fluxes and disturbance-induced losses, Science, 302, 15541557

Sellers, P. J., J. A. Berry, G. J. Collatz, C. B. Field, and F. G. Hall (1992), Canopy reflectance, photosynthesis, and transpiration. III. A reanalysis using improved leaf models and a new canopy integration scheme, Remote Sens. Environ., 42, 187-216.

Sombroek, W. G. (2001), Spatial and temporal patterns of Amazon rainfall: Consequences for the planning of agricultural occupation and the protection of primary forests, Ambio, 30, 388-396.

Tian, H., J. M. Melillo, D. W. Kicklighter, A. D. McGuire, J. V. K. Helfrich III, B. Moore III, and C. J. Vörösmarty (1998), Effect of interannual climate variability on carbon storage in Amazonian Ecosystems, Nature, 396, 664-667.

von Randow, C., et al. (2004), Comparative measurements and seasonal variations in energy and carbon exchange over forest and pasture in south west Amazonia, Theor. Appl. Climatol., 78, 5-26.

Vourlitis, G. L., N. P. Filho, M. M. S. Hayashi, J. de S. Nogueira, F. T. Caseiro, and J. H. Campelo Jr. (2001), Seasonal variations in the net ecosystem $\mathrm{CO}_{2}$ exchange of a mature Amazonian transitional tropical forest (cerradão), Funct. Ecol., 15, 388-395.

Wright, S. J., and C. van Schaik (1994), Light and the phenology of tropical trees, Am. Nat., 143, 192-199.

Xiao, X., Q. Zhang, S. Saleska, L. Hutyra, P. de Camargo, S. Wofsy, S. Frolking, S. Boles, M. Keller, and B. Moore III (2005), Satellite-based modeling of gross primary production in a seasonally moist tropical evergreen forest, Remote Sens. Environ., 94, 105-122.

K. Didan, A. R. Huete, and P. Ratana, Department of Soil, Water and Environmental Science, University of Arizona, 429 Shantz Building 38, Tucson, AZ 85721-0038, USA. (ahuete@ag.arizona.edu)

L. R. Hutyra, Department of Earth and Planetary Sciences, Harvard University, 20 Oxford Street, Cambridge, MA 02138, USA.

R. Myneni and W. Yang, Department of Geography, Boston University, 675 Commonwealth Avenue, Boston, MA 02215, USA.

R. R. Nemani, NASA Ames Research Center, Moffett Field, CA 94035 , USA.

S. R. Saleska, Department of Ecology and Evolutionary Biology, University of Arizona, 1041 E. Lowell Street, Tucson, AZ 85721, USA.

Y. E. Shimabukuro, Instituto Nacional de Pesquisas Espaciais, Av. dos Astonautas, 1758, São José dos Campos, CEP 12227-010, Brazil. 